\title{
Management of a primary cardiac leiomyosarcoma in a young woman
}

\author{
Genç bir kadında primer kardiyak leiomyosarkom tedavisi

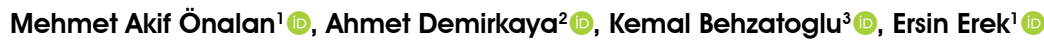 \\ 'Department of Cardiovascular Surgery, Acıbadem Mehmet Ali Aydınlar University Faculty of Medicine, Istanbul, Turkey \\ 'Department of Thoracic Surgery, Acıbadem Mehmet Ali Aydınlar University Faculty of Medicine, Istanbul, Turkey \\ ${ }^{3}$ Department of Pathology, Acıbadem Mehmet Ali Aydınlar University Faculty of Medicine, Istanbul, Turkey
}

\begin{abstract}
Cardiac leiomyosarcoma is an extremely rare tumor with a poor prognosis. An 18-year-old female patient was admitted to our clinic with a left atrial leiomyosarcoma extending to the right lower pulmonary veins. We performed complete tumor excision by the right anterolateral mini-thoracotomy approach using minimally invasive techniques. After pathological confirmation of the tumor, right lower lobectomy was performed with the same incision one week later to prevent recurrence. Although no tumor remnant was found in the lobectomy specimen, adjuvant chemotherapy was started. No recurrence was detected during the 12-month follow-up. In conclusion, the right submammarian minithoracotomy approach has the advantages of its less invasive nature and suitability for complete tumor resection with lobectomy.
\end{abstract}

Keywords: Cardiac neoplasm, leiomyosarcoma, surgery.

Cardiac tumors are very rare neoplasms with a frequency of $0.02 \%$, and only $25 \%$ of them are malignant. ${ }^{[1]}$ The most common histological type of primary cardiac tumors is angiosarcoma, and leiomyosarcomas appear in less than $1 \%$ of cases. ${ }^{[1]}$ Despite aggressive multidisciplinary treatment, the prognosis of leiomyosarcoma is poor with a median survival of approximately 12 months. ${ }^{[2,3]}$ In this case report, we present the successful management of leiomyosarcoma in a young woman.

\section{$\ddot{O} Z$}

Kardiyak leiomyosarkom, kötü prognozlu, oldukça nadir görülen bir tümördür. Sağ alt pulmoner venlere uzanan sol atriyal leiomyosarkomu olan 18 yaşında bir kadın hasta kliniğimize başvurdu. Minimal invaziv teknikler kullanarak, sağ anterolateral mini torakotomi yaklaşımı ile tümörün tam eksizyonu gerçekletirildi. Tümörün patolojik olarak doğrulanmasının ardından bir hafta sonra aynı kesi ile nüksü önlemek için sağ alt lobektomi yapıldı. Lobektomi örneğinde tümör kalıntısı bulunmamasına rağmen, adjuvan kemoterapi başlandı. Hastanın 12 aylık takibinde nüks tespit edilmedi. Sonuç olarak, sağ submammarian minitorakotomi yaklaşımı, daha az invaziv olması ve lobektomi ile tümörün tam rezeksiyonu için uygun olması avantajlarına sahiptir.

Anahtar sözcükler: Kardiyak tümör, leiomyosarkom, cerrahi.

\section{CASE REPORT}

An 18-year-old female patient was admitted to our hospital with mild dyspnea and a preliminary diagnosis of respiratory infection. The diagnosis was confirmed by cardiac magnetic resonance imaging (MRI), which showed a $4.4 \times 3 \times 2.2-\mathrm{cm}$ mass in the left atrium, extending to the right inferior pulmonary vein. A transthoracic and transesophageal echocardiogram showed a mass with little mobility in the left atrium (Figure 1a-c). Positron emission tomography

Received: October 29, 2020 Accepted: January 25, 2021 Published online: April 26, 2021

Correspondence: Mehmet Akif Önalan, MD. Acıbadem Mehmet Ali Aydınlar Üniversitesi Tıp Fakültesi, Kalp ve Damar Cerrahisi Anabilim Dalı, 34684 Ataşehir, İstanbul, Türkiye. Tel: +90 212 - 4142000 e-mail: mehmetakifonalan@gmail.com 

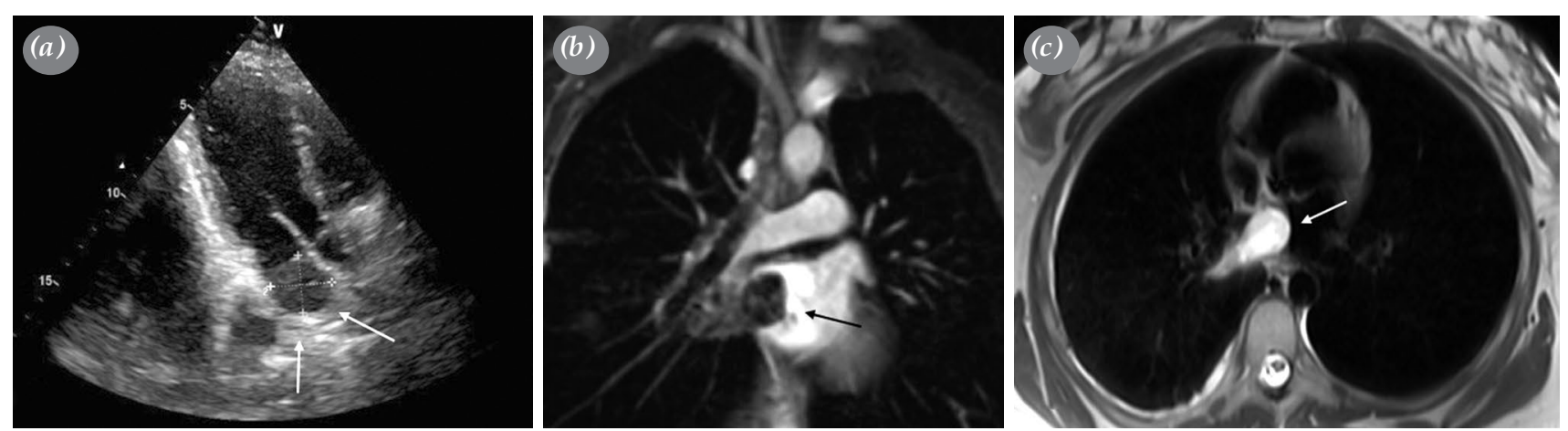

Figure 1. (a) Transesophageal echocardiography and $(\mathbf{b}, \mathbf{c})$ cardiac magnetic resonance imaging showing a left atrial mass extending into pulmonary vein.

(PET)-computed tomography (CT) revealed high fluorodeoxyglucose (FDG) uptake in the mass, and surgery was planned. A written informed consent was obtained from the patient.

Due to the potential need for lung resection, a right submammary mini-thoracotomy approach was chosen. A submammary skin incision was performed, and the mammary gland was dissected from the fascia to expose the fourth rib. Cardiopulmonary bypass (CPB) was started, after aortic and bicaval cannulation via the same incision. A right atriotomy incision was performed, the interatrial septum was opened, and the mass in the left atrium was reached. The tumor had a stable consistency; there was no necrosis or ulceration on its surface, and it was gently attached to the left atrial wall with a thin capsule. The tumor extended to the bifurcation of the right lower pulmonary vein branches and could be entirely excised with its pedicle (Figure 2). Cold saline was used to rinse the heart chambers, and careful examination was performed to ensure complete resection.

The tumor was evaluated by examining frozensection; however, it could not be classified as a benign or malignant neoplasm intraoperatively. Therefore, we did not perform lymph node dissection or right lower lobectomy. The patient was discharged from the hospital on postoperative Day 6. On histopathological evaluation, multiple sections revealed pleomorphic spindle tumor cell fascicles with nuclear hyperchromasia. Atypical mitosis was also observed (14 mitoses/10 HPF) with coagulation necrosis. Reactions for actin and desmin were positive, and those for CD34 and S100 were negative (Figure 3). A total of $30 \%$ positivity was shown by tumor cells for $\mathrm{Ki}-67$, and these immunohistochemical features were compatible with a leiomyosarcoma.

After histopathological confirmation of leiomyosarcoma, our multidisciplinary team
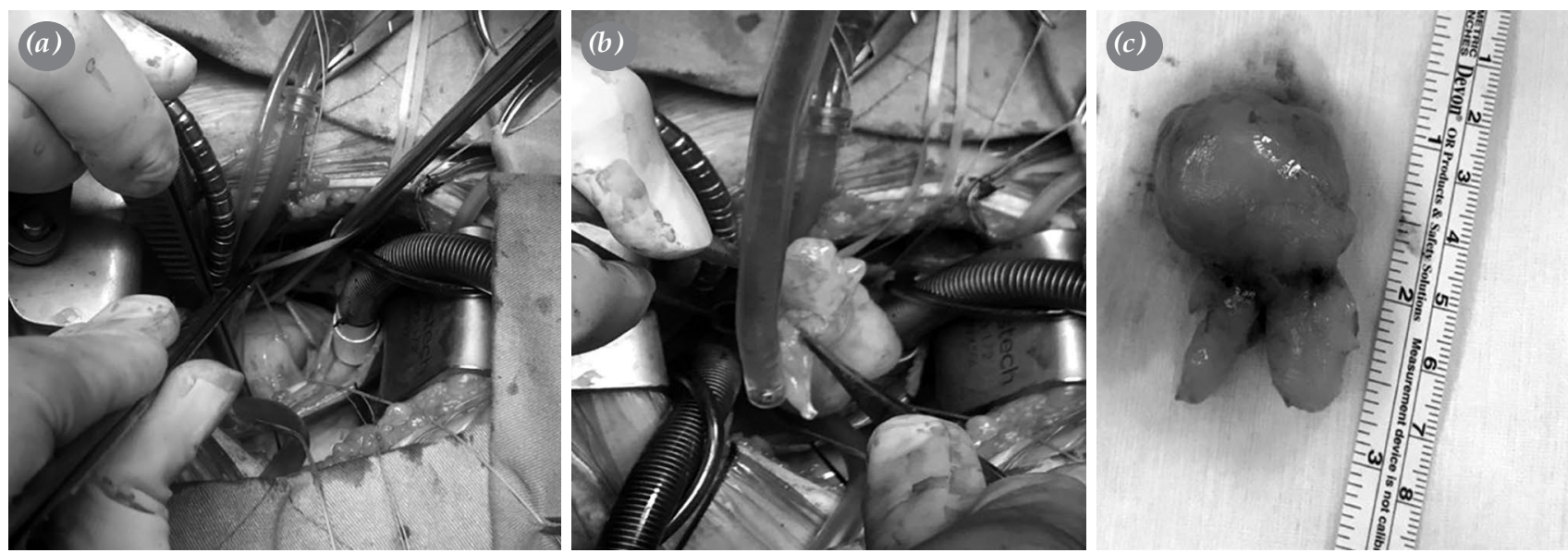

Figure 2. (a) Intraoperative view of cardiac tumor in left atrium. (b, c) The resected left atrial tumor showed a smooth white surface without any necrosis or ulceration. 

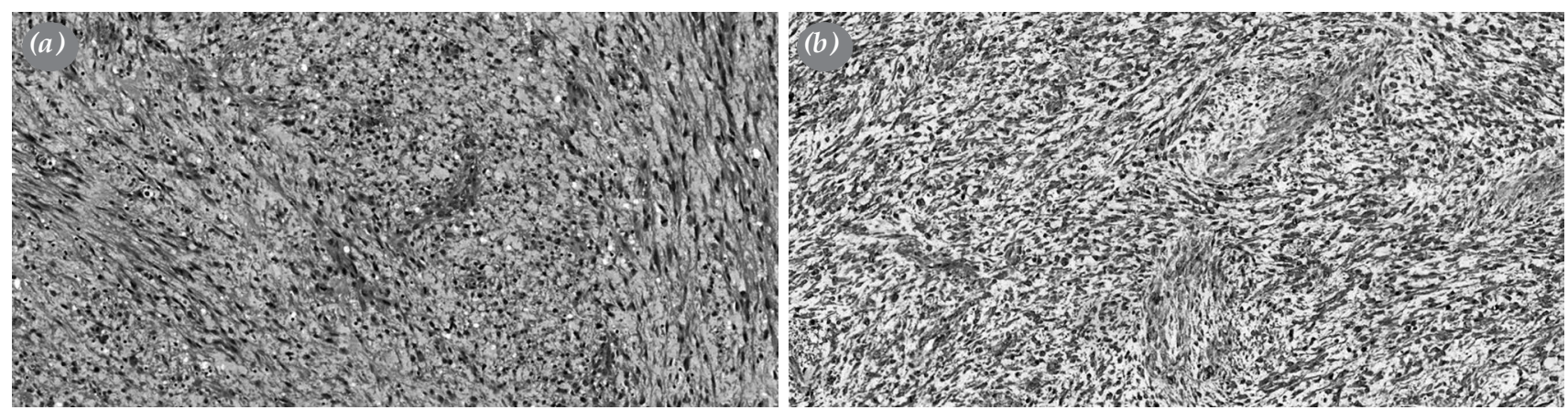

Figure 3. (a) Histopathological analysis showing a sarcomatous lesion with epithelioid neoplastic cells (H-E, $\times 400)$. (b) Immunohistochemical staining showing diffuse cytoplasmic immunoreactivity of smooth muscle actin $(\mathrm{H}-\mathrm{E}, \times 100)$.

H-E: Hematoxylin and eosin.

decided to perform right lower lobectomy to ensure complete resection of the tumor and to prevent its recurrence. Right lower lobectomy with right inferior pulmonary vein excision, mediastinal lymph node dissection and partial left atrial resection were performed without CPB via the previous incision. The patient was discharged on postoperative Day 7. Histopathological examination revealed that the resected pulmonary vein and left atrial specimen borders were histologically clear.

At the discretion of the multidisciplinary team, adjuvant chemotherapy, consisting of four cycles of doxorubicin and ifosfamide, was prescribed by the medical oncology department. She also received adjuvant cardiac radiotherapy (54 Gy in 27 fractions) at the fifth postoperative month. The patient was regularly followed, and no metastasis was detected on PET-CT and thoracic MRI at four and six months of follow-up. After a follow-up of 12 months, she had still no clinical or radiological evidence of recurrence.

\section{DISCUSSION}

In the literature, there are few reports of limited cases of primary cardiac leiomyosarcoma at younger ages. In a systematic review, Wang et al. ${ }^{[3]}$ identified 79 instances of primary cardiac leiomyosarcomas from 72 unique reports. The recurrence-free survival and five-year overall survival rates were $14.7 \%$ and $25.4 \%$, respectively.

Early diagnosis and adequate surgical resection remain the mainstays of this tumor. ${ }^{[2]}$ Adjuvant radiotherapy and chemotherapy have been shown to prolong survival and improve disease control in some cases. ${ }^{[4]}$ Patel et al. ${ }^{[5]}$ from the Mayo Clinic reported a 58-year-old male patient with a primary pulmonary vein leiomyosarcoma which extended to the left atrium, and the patient underwent right lower lobectomy with resection and reconstruction of the left atrial wall. Adequate excision of a pulmonary vein tumor may require lung resection, ranging from lobectomy to pneumonectomy. ${ }^{[2,5]}$ In our case, the left atrial tumor extended to the branches of the pulmonary veins, and therefore, right inferior lobectomy with right inferior pulmonary vein excision was performed to reach the clean surgical margin. Adjuvant radiotherapy and chemotherapy were administered to our patient based on the decision of the multidisciplinary team.

The necessity of lung resection is high for this type of tumor, due to the pulmonary vein extension. It may be difficult to perform through median sternotomy, and additional right thoracotomy may be needed. Based on our experience, the right submammary mini-thoracotomy approach is feasible and effective for both cardiac tumor resection and right lower lobectomy.

A younger age at the time of diagnosis, an inadequate surgical margin, high-grade histological features, and a large tumor size are all considered to be risk factors for poor survival. ${ }^{[6]}$ According to the literature on cardiac leiomyosarcomas, the mean survival of patients who underwent surgery and chemotherapy was approximately 12 months..$^{[2,3]}$ In our case, the patient is still alive, and there is no evidence of local or distant recurrence or metastasis after a follow-up of 12 months.

In conclusion, cardiac leiomyosarcoma is an extremely rare tumor with a poor prognosis, and frozen section-guided complete resection is the key to treatment. Adjuvant chemoradiotherapy may further prolong survival, and regular echocardiography 
should be performed after the operation. The right submammarian minithoracotomy approach has the advantages of its less invasive nature and suitability for complete tumor resection with lobectomy.

\section{Declaration of conflicting interests}

The authors declared no conflicts of interest with respect to the authorship and/or publication of this article.

\section{Funding}

The authors received no financial support for the research and/or authorship of this article.

\section{REFERENCES}

1. Patel J, Sheppard MN. Pathological study of primary cardiac and pericardial tumours in a specialist UK Centre: Surgical and autopsy series. Cardiovasc Pathol 2010;19:343-52.
2. Gukop P, Frassetto G, Karapanagiotidis G, Chandrasekaran V. Leiomyosarcoma of pulmonary vein presenting as left atrial mass: An outline of management principles. Case Rep Cardiol 2012;2012:396319.

3. Wang JG, Cui L, Jiang T, Li YJ, Wei ZM. Primary cardiac leiomyosarcoma: An analysis of clinical characteristics and outcome patterns. Asian Cardiovasc Thorac Ann 2015;23:623-30.

4. Morin JE, Rahal DP, Hüttner I. Myxoid leiomyosarcoma of the left atrium: A rare malignancy of the heart and its comparison with atrial myxoma. Can J Cardiol 2001;17:331-6.

5. Patel SM, Kadakia KC, Maleszewski JJ, Marks RS. Straight to the heart: Pulmonary vein leiomyosarcoma. Am J Med 2013;126:117-9.

6. Elbardissi AW, Dearani JA, Daly RC, Mullany CJ, Orszulak TA, Puga FJ, et al. Survival after resection of primary cardiac tumors: A 48-year experience. Circulation 2008;118(14 Suppl):S7-15. 